\title{
Review of the historical distribution of the Lesser White-fronted Goose Anser erythropus in Europe
}

\author{
Översikt av den historiska utbredningen av fjällgås Anser erythropus $i$ Europa
}

JOHAN H. MOOIJ

\begin{abstract}
The Lesser White-fronted Goose Anser erythropus showed a dramatic decline since the first population estimates of the 1950s. At most wintering sites the species was overlooked until the middle of the 20th century and the migratory routes, staging areas and wintering sites were poorly known. Population modelling under consideration of the official estimates of the size of the total Lesser White-fronted Goose population since the 1950s indicates the possibility that the species population may have reached a level of 250,000-300,000 individuals in the second half of the 19 th century, which means that the decline probably started already at the middle of the 19th
\end{abstract}

century. Records from hunting, catching and observations in wintering and staging areas indicate that Lesser White-fronted Geese not only migrated over western Siberia and eastern Europe but also over western Europe. Because hunting is still one of the major threats, the species can only be saved from extinction if the key sites are protected and hunting of all goose species is banned in all staging areas of the species.

Johan H. Mooij, Biological Station Wesel, Freybergweg 9, D-46483 Wesel,Germany; E-mail:johan.mooij@bskw.de

\section{Introduction}

The Lesser White-fronted Goose Anser erythropus is a monotypic and exclusively Palaearctic species that apparently separated from the Greater Whitefronted Goose Anser albifrons about 175,000 years ago (Pedall et al. 2008). Both species are morphologically and genetically still very similar. Alphéraky (1904) stated that the species most probably was breeding throughout the tundra zone of northern Eurasia from Kamchatka to Lapland and was wintering in Western Europe, Greece, Turkey, northern Egypt, Persia, India, South-China and Japan. Nowadays the breeding area is disjunct and the main wintering areas seem to be in Iraq and South China, with small numbers still wintering in the border region of Greece and Turkey (Aarvak \& Timonen 2004).

The Lesser White-fronted Goose is included in Appendix 1 of the African-Eurasian Waterbird Agreement (AEWA) under the Bonn Convention, in Appendix II of the Bern Convention, and in Appendix I of the EU-Birdsdirective. In 2008 AEWA adopted and published an International Single Spe- cies Action Plan for the Western Palaearctic population of the species (AEWA 2008).

In this study, historical records of Lesser Whitefronted Geese are presented and analysed in an effort to delineate historical migratory routes as well as population development since the middle of the 19 th century.

\section{Methods}

Records were collected from literature (Alphéraky 1904, Bauer \& Glutz von Blotzheim 1968, Davies 1949, Davis \& Scott 1946, De Smet 2005, Drobovtsev 1972, Dubois et al. 2000, Dzieciolowski \& Frankiewicz 1970, Eykman et al. 1941, Faragó 1995, Fransson \& Pettersson 2001, Handrinos \& Goutner 1990, Kampe-Persson 2004, 2008, Klemm \& Kohl 1988, Koffijberg et al. 2005, Kumari \& Jögi 1972, Leibak et al. 1994, LOB 2007, Mooij \& Heinicke 2007, 2008, Mooij et al. 2008, Norderhaug \& Norderhaug 1982, 1984, Noskov 2002, Pachenko \& Priklonski 1972, Persson 2000, 2004, Prokosch \& Hötker 1995, Raudonikis \& Shvazhas 1991, Rogacheva 1992, Salmen 1980, 
Sterbetz 1968, 1982, Smith 1974, Švažas 1996, Švažas et al. 1997 \& 1998, Tischler 1914, Thienemann 1907, 1908, Tkachenko \& Litvinova 1990, Tomiałojc 1990, Van Impe 1982, Van Oort 1909, Vinogradov 1990, Vlaamse Avifaunacommissie 1989, Von Transehe 1965, Watson 1955, Witherby et al. 1939, Yeatman-Berthelot 1991, Žalakevičius 1998), and from data banks of BTO, DOF, SOVON, SVALAN, and ZMA. I also used data from birds with transmitters (http://www.piskulka. net, http://gis-lab.info/projects/piskulka-eng.html) and personal communication with a number of colleagues.

Releases of Lesser White-fronted geese started in Sweden in 1981 (von Essen 1982, 1991, 1996). To exclude records of these birds, only data from the period up to 1982 were used. All observations were supplied with geographical coordinates and fed into "ArcView" GIS. Double entries were deleted so that a record was considered only once.

\section{Results}

\section{Records of Lesser White-fronted Geese}

A total of 986 records was accepted for analysis, of which about three quarters dated from after 1960. The average number of birds observed per record increased until the 1920s and was then more or less stable, with exception of the 1970s (Table 1). The higher average of that decade was a result of a special monitoring programme in Hungary (Sterbetz 1976, 1982). Most records concerned single or few birds. Higher numbers $(>100$ indi-

Table 1. Records of Lesser White-fronted Geese in Europe 1850-1982.

Fynd av fjällgäss i Europa 1850-1982

\begin{tabular}{lrrr}
\hline Period & $\begin{array}{r}\text { Number } \\
\text { of records } \\
\text { Antal }\end{array}$ & $\%$ & $\begin{array}{r}\text { Number of } \\
\text { birds/record } \\
\text { Antal fäglar } \\
\text { per rapport }\end{array}$ \\
\hline before 1900 & 28 & 2.8 & 1.17 \\
$1900-1909$ & 22 & 2.2 & 5.75 \\
$1910-1919$ & 17 & 1.7 & 12.27 \\
$1920-1929$ & 22 & 2.2 & 34.45 \\
$1930-1939$ & 42 & 4.3 & 21.84 \\
$1940-1949$ & 27 & 2.7 & 49.20 \\
$1950-1959$ & 66 & 6.7 & 12.85 \\
$1960-1969$ & 254 & 25.8 & 32.27 \\
$1970-1979$ & 371 & 37.7 & 107.33 \\
$1980-1982$ & 137 & 13.9 & 44.88 \\
\hline & 986 & 100.0 & 32.20
\end{tabular}

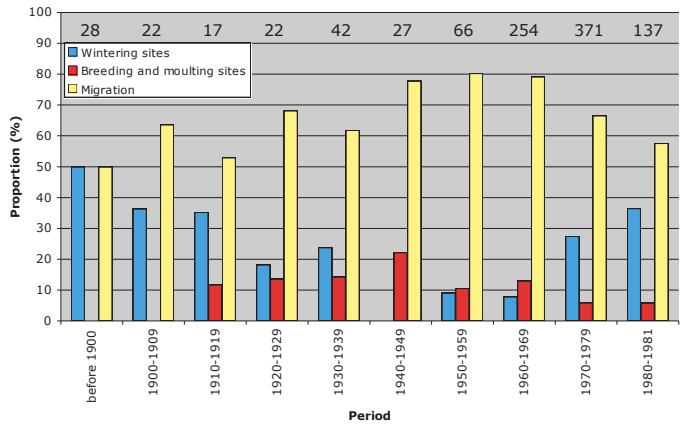

Figure 1. Records of Lesser White-fronted Geese in Europe until 1982 divided according to their origin.

Fynden av fjällgäss i Europa fram till 1982 uppdelade på deras ursprung: övervintringsplatser (blått), häck- och ruggplatser (rött) och fynd under flyttningen (gult).

viduals) were recorded in the Swedish breeding sites (1910s-1940s) and the Evros delta in Greece (1960s-1970s).

The number of records (Table 1) increased in the 1930s, dropped during the 1940s but increased again after the war in spite of the dramatic decline of the population, which illustrates the growing interest in the species. The proportion of records from breeding and moulting areas, wintering areas and staging areas per decade is given in Figure 1. Up to the 1910 s there were no records from the breeding and moulting areas. In all periods the majority of the records originated from the staging areas along the migratory routes. The proportion of records from the wintering areas declined in the 1920 s but increased again in the 1970s.

\section{Geographical distribution of the records over the study period}

The records from before 1900 represent birds that were shot or caught by professional goose catchers. A considerable number of these birds are now in scientific collections in western Europe: Belgium (2 records), Germany (12), the Netherlands (5), the United Kingdom (4), Lithuania (1), Poland (1), Sweden (1), Spain (1) and Greece (1 record).

The records from the period 1900-1949 (Figure 2) mainly concerned birds collected during hunting or catching through the 1930s. Then interest in the species increased and the number of birds observed in the field grew considerably. Besides observations from the Fennoscandian breeding areas there is a considerable number of observations from the Baltic States, Denmark, Northern Germany and the 


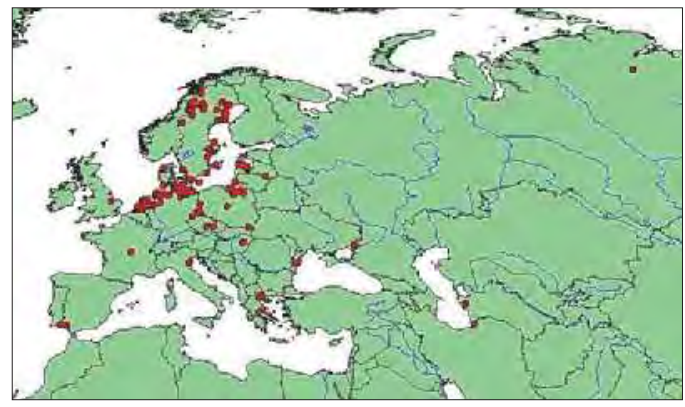

Figure 2. Distribution of Lesser White-fronted Goose records in the period 1900-1949.

Utbredningen av fjällgåsfynden under perioden 1900-1949.

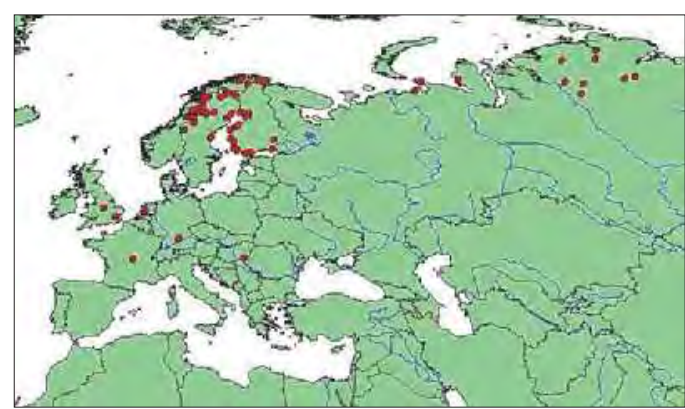

Figure 4. Distribution of Lesser White-fronted Goose records in summer (June-August).

Utbredningen av fjällgåsfynden under sommaren (juni-augusti).

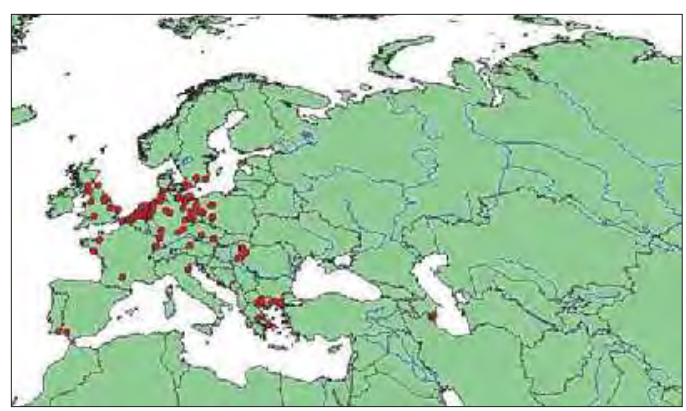

Figure 6. Distribution of Lesser White-fronted Goose records in winter (December-Febrary).

Utbredningen av fjällgåsfynden under vintern (december-februari).

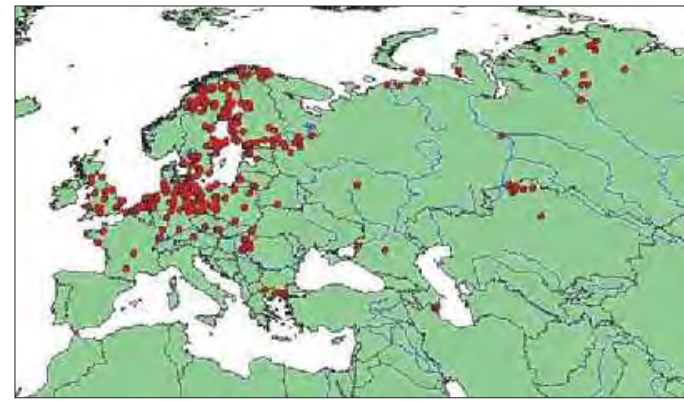

Figure 3. Distribution of Lesser White-fronted Goose records in the period 1950-1982.

Utbredningen av fjällgåsfynden under perioden 1950-1982.

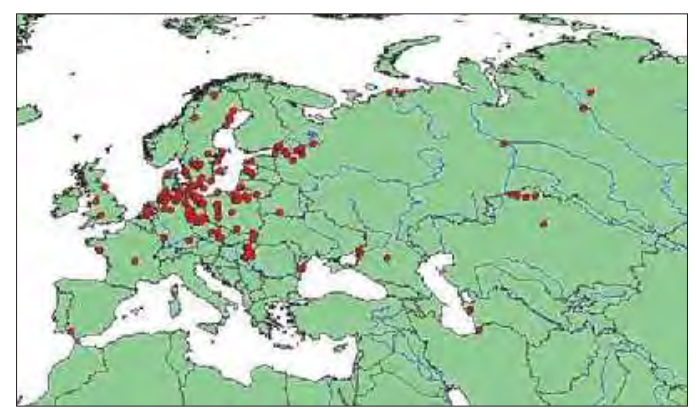

Figure 5. Distribution of Lesser White-fronted Goose records in autumn (September-November).

Utbredningen av fjällgåsfynden under hösten (septembernovember).

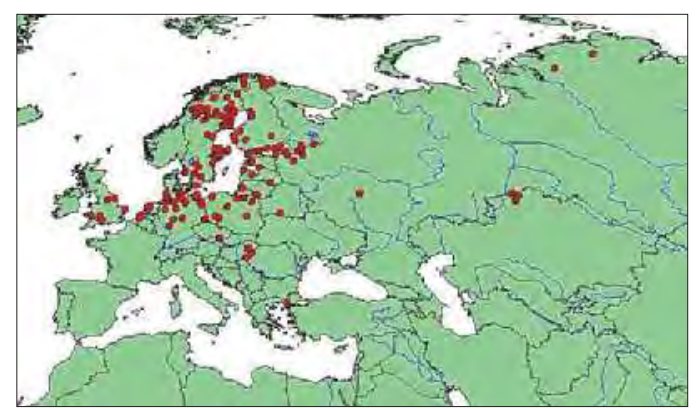

Figure 7. Distribution of Lesser White-fronted Goose records in spring (March-May).

Utbredningen av fjällgåsfynden under våren (mars-maj). 
Netherlands, Poland and southern Sweden, but also single observations in other countries.

In the period 1950-1982 not only the number of records showed a considerable increase, but the records were also much more spread over Europe than in the earlier periods. The highest concentrations were reported from the Baltic States, Finland, Germany, Hungary, the Netherlands, Poland, Sweden and the United Kingdom (Figure 3).

\section{Seasonal distribution of the records}

Summer (June, July, August) records concerned birds staying in the traditional breeding and moulting areas (Figure 4). The records outside these areas in France, Germany, Hungary, the Netherlands and the United Kingdom most certainly are birds escaped from captivity or injured by hunting. The records along the Bothnian coast of Sweden and Finland most likely refer to non-breeders.

Autumn (September, October, November) records are spread over most of Europe as well as along a flyway through western Siberia via northern Kazakhstan to the Black and the Caspian Sea (Figure 5). Focal areas are the coast of the Baltic States, the Leningrad Oblast in northern Russia, southern Sweden, Poland, the northern part of Germany, the former Czechoslovakia, Hungary and northern Kazakhstan.

Winter (December, January, February) records came from Belgium, France, Germany, the Netherlands, the United Kingdom and western Poland as well as Italy and the Iberian peninsula, furthermore from Greece, Azerbaijan, and northern Iran (Figure 6).

Spring (March, April, May) records concentrate again in northern Europe and northern Kazakhstan. In Europe most records came from the Baltic States, northern Germany, Poland, Sweden, Finland and northern Russia. Further records came from Greece, Hungary, the Netherlands and the United Kingdom (Figure 7).

\section{Historical population level and development}

There are no estimates of the actual size of the population until the middle of the 20th century. But Scott (1939) reports concentrations of at least 30,000-60,000 Lesser White-fronted Geese at the southern coasts of the Caspian Sea, and Sterbetz $(1968,1976,1982)$ estimated the peak number of Lesser White-fronted Geese in the Hortobágy Puszta at 80,000-120,000 individuals in the first half of the 20th century and after the dramatic decrease at less than 5000 individuals in the 1960s. Vinogradov (1990) estimated that c. 100,000 Lesser White-fronted geese annually passed through northern Kazakhstan in the middle of the 20th century, c. 60,000 birds the KumaManych depression and c. 15,000 the coasts of the Sea of Azov. In the Kizil Agach area in Azerbaijan the former winter population size was said to be 35,000-40,000, but in 1996 only about 1000 Lesser White-fronted Geese could be found (Paynter 1996). At the end of the 19th century high numbers passed annually over the Aral Sea, but around the 1950s only single birds flew along this route (Alphéraky 1904, Vinogradov 1990). Considering these data a population estimate of at least 200,000 Lesser White-fronted Geese in the Western Palearctic in the first half of the 20th century does not seem unrealistic.

For the late 1970s, Yu. N. Mineev estimated for the Bolshezemelskaya Tundra a population of 3600-5400, V.N. Kalyakin \& V.G. Vinogradov for the southern Yamal Peninsula c. 10,000 and A.S. Martynov for the southern Taimyr Peninsula c. 110,000 individuals (Rogacheva 1992, Vinogradov 1990). Although Rogacheva (1992) considered the estimate of Martynov "tentative and highly overestimated" a population estimate for the Russian arctic for the late 1970s of at least c. 100,000 Lesser Whitefronted Geese seems realistic. Since then the population decreased to a level of less than 15,000 birds until the 1990s (Lorentsen et al. 1999) and to c. 10,000 birds in 2000 (Morozov 2006, Morozov \& Syroechkovski Jr. 2005).

\section{Hunting}

Since the 1980s on most regularly monitored sites the population numbers decreased with about $5 \%$ annually (Tolvanen et al. 2004). In spite of the fact that the Lesser White-fronted Goose has been a non-quarry species for a number of decades in most of its living range, hunting pressure did not substantially change during the past century (Table 2). The current total bag is estimated at 2400 birds (Mooij 2005).

\section{Discussion}

\section{Historical migration pattern}

The distribution of records (Figure 3-7) indicates that Lesser White-fronted Geese not only migrated over western Siberia and eastern Europe as described in Madsen et al. 1999 and AEWA 2008. At least during the study period there was also a 
Table 2. Regional hunting pressure on the Lesser White-fronted Goose according to literature data (e.g. Flint pers.comm., Kellomäki pers.comm., Sterbetz 1968, Tolvanen \& Pynnönen 1998, Vinogradov 1990, Yerokhov pers.comm, Yerokhov et al. 2008).

Regionalt jakttryck på fjällgåsen enligt litteraturdata (referenser ovan).

\begin{tabular}{llrrr}
\hline Country & Year & $\begin{array}{r}\text { LWfG } \\
\text { Fjällgås }\end{array}$ & $\begin{array}{r}\text { Bag } \\
\text { Alla gäss }\end{array}$ & $\%$ \\
\hline Hungary (Hortobágy) & $1920-1925$ & 62 & 956 & 6.5 \\
Hungary (Hortobágy) & 1934 & 90 & 783 & 11.5 \\
Hungary (Hortobágy) & 1936 & 4 & 16 & 25.0 \\
Kazakhstan (Kostanay Region) & 1963 & 5 & 60 & 8.3 \\
Hungary (Hortobágy) & 1966 & 34 & 86 & 39.5 \\
Russian Federation (Purynsky Lake, Taimyr) & 1967 & - & - & 27.0 \\
Russian Federation (Pura river, Taimyr) & 1972 & 8 & 33 & 24.2 \\
Russian Federation (Chelyabinsk Region) & $1987-1996$ & - & - & $10-40$ \\
Kazakhstan (Steppe area) & 1980 s & & & $c .10$ \\
Kazakhstan (Kostanay Region) & 1996 & 6 & 111 & 5.4 \\
Kazakhstan (Kostanay Region) & 1997 & 1 & 24 & 4.2 \\
Kazakhstan (Kostanay Region) & 1997 & 2 & 13 & 7.7 \\
Kazakhstan (Kostanay Region) & 1998 & 1 & 66 & 14.3 \\
Kazakhstan (Kostanay Region) & 1999 & 0 & 4 & 1.5 \\
Kazakhstan (Kostanay Region) & 2000 & 2 & 33 & 0.0 \\
Kazakhstan (Kostanay Region) & 2001 & 3 & 123 & 6.1 \\
Bulgaria & 2002 & 4 & 51 & 2.4 \\
Kazakhstan (Kostanay Region) & 2002 & 1 & 4 & 25.8 \\
Russian Federation (St.Petersburg) & 2003 & 7 & 31 & 22.6 \\
Russian Federation (Karelia) & 2003 & 0 & 3 & 0.0 \\
Kazakhstan (Kostanay Region) & 2003 & 6 & 17 & 35.3 \\
Kazakhstan (Lake Biyesoigan) & 2004 & 10 & 195 & 5.1 \\
Kazakhstan (Lake Kostanay) & 2006 & &
\end{tabular}

regular migratory route to a number of Western European countries.

Pooling all records in one map (Figure 8A) indicates the existence of a number of migration routes in the Western Palearctic (Figure 8B). The available data do not give information about the historical importance of each of these different flyways, but high numbers of Lesser White-fronted Geese were recorded in the Kuma-Manych Valley and the coast of the Sea of Azov in Russia (Alphéraky 1904, Vinogradov 1990), south of the Caspian Sea (Scott 1939), the Hortobágy Puszta in Hungary (Sterbetz 1968, 1982), Swedish Lapland (Norderhaug \& Norderhaug 1982, 1984), the Evros Delta in Greece (Handrinos \& Goutner 1990) and the steppe areas around the Aral Sea and in northern Kazakhstan (Alphéraky 1904, Vinogradov 1990). The numbers recorded in western Europe were rather small most of the time.

In the 19th century and also in the early decades of the 20th century most geese were staging in more or less remote areas. Besides, until the 1980s in most of Europe there were hardly any ornithologists with good equipment and most of them had limited mobility. As a result most goose haunts were seldom or irregularly visited by ornithologists and even if regional goose concentrations were checked, Lesser White-fronted Geese were easily overlooked. Therefore all Lesser White-fronted Goose data from the period before the 1980s were more or less collected by chance and are rather poor. For that reason it is not possible to make any statements about the importance of each of the delineated migratory routes and staging areas during the study period.

There are hardly any historical records from the Baltic States, where a considerable number of Lesser White-fronted Geese must have crossed in the past (Kumari \& Jögi 1972, Leibak et al. 1994, LOB 2007, Raudonikis \& Shvazhas 1991, Švažas 1996, Švažas et al. 1997 \& 1998, Von Transehe 1965). From Greece there are only two records of Lesser White-fronted Geese from the 19th and only four from the first half of the 20th century, although 
Figure 8. (A) Distribution of all Lesser White-fronted Goose records of this study (red) combined with records of birds with satellite transmitters (blue). (B) Possible migratory network based on breeding and moulting sites (green dots), staging areas during migration (brown dots) and wintering sites (blue dots). The red line is the $0^{\circ}$ winter isotherm.

(A) Utbredningen av alla fjällgåsfynd från denna studie (röda punkter) kombinerade med registreringar från satellitförsedda gäss (blå punkter). (B) Möjligt nätverk för flyttvägarna mellan häck- och ruggplatser (gröna cirklar), rastplatser under flyttningen (bruna cirklar) och övervintringsplatser (blå cirklar). Den röda linjen visar isotermen för noll grader under vintern.

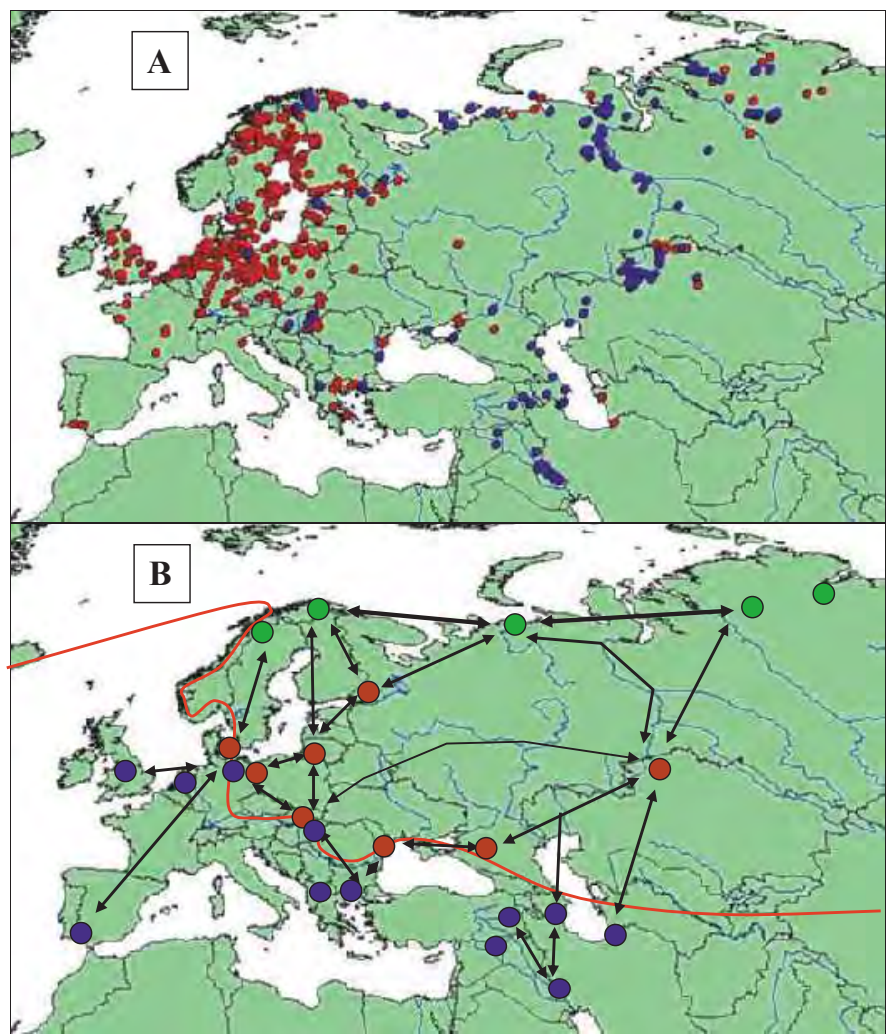

almost certainly the species must have wintered in the country in considerable numbers in that period (Handrinos \& Goutner 1990). In Hungary the situation was not much different (Sterbetz 1968).

In Naumann (1842) and Stresemann (1961), the Lesser White-fronted Goose was described as a rare and in Frieling (1936) and Niethammer (1938) as a "not rare" and regular migrant and winter guest in Germany, while Bauer \& Glutz von Blotzheim (1968) stated that it was a regular migrant in the eastern part of the north European lowlands, in some years in large flocks. In spite of the fact that the species seemed to be a rare migrant in most of Germany, the species was recorded in most parts of the country.

From 1945, as Peter Scott started Lesser Whitefronted Goose monitoring in Great Britain, until 1980 the species was annually recorded with one to three birds, associated with Greater White-fronted Geese at Slimbridge in Gloucestershire as well as in Bean Goose flocks in Norfolk and Scotland (Davies 1949, Davis \& Scott 1946, Smith 1974,
Watson 1955). These were "undoubtedly wild birds" (Ogilvie \& Wallace 1975).

Although there are hardly any records of larger Lesser White-fronted Goose flocks along the West European/Atlantic migratory route from the 19th and the first half of the 20th century this is no proof that such a route never existed. Also from most East European staging areas such historical information is lacking. On the contrary, the data of this study show that there are a comparably high number of records from western Europe from this period, which indicate that in former times a migratory route to western Europe very well could have existed. That small numbers still follow this route is indicated by more recent data published by De Smet 2005, Heinicke \& Mooij 2005, KampePersson 2004, 2008, Koffijberg et al. 2005, Mooij \& Heinicke 2007, 2008, and Mooij et al. 2008.

\section{Lesser White-fronted Goose as a species}

The Lesser White-fronted Goose was described as 
a species in the 18th century (Linnæus 1758), but at most wintering sites the species was overlooked until the middle of the 20th century and the migratory routes, staging areas and wintering sites were poorly known. That's why there are hardly any data about the occurrence of the Lesser White-fronted Goose before the 20th century.

Middendorff $(1853,1867)$ classified the Lesser White-fronted Goose as a "circumboreal tundra bird species" that was more common than the Greater White-fronted Goose along the Taimyr and Boganida rivers. In the middle of the 19th century, Nilsson (1858) reported that two white-fronted goose species occurred in Scandinavia and Schlegel (1877) described the Lesser White-fronted Goose as a subspecies of the Greater White-fronted Goose, but noted that it also could be described as a separate species. Hudson (1895) did not recognise the Lesser White-fronted Goose as a species. Alphéraky (1904) stated that there cannot be any doubt about the fact that the Lesser White-fronted Goose is a separate species, but that the delineation of the species' flyways is difficult, because it is not separated from the Greater White-fronted geese at most sites by hunters and ornithologists. But Witherby et al. (1939) states "Further research may show that the breeding-ranges of this bird and the White-fronted Goose do not overlap, in which case they may perhaps be treated as forms of one species." This statement was still included in the 5 th edition of the "Handbook of British Birds" of 1948.

\section{Historical distribution of the Lesser White-fronted Goose in literature}

Apart from Alphéraky (1904), the distribution of the Lesser White-fronted Goose has been described by Witherby et al. (1939), Dementiev \& Gladkov (1952) and Uspenski (1965). There are only minor differences in their accounts, and they support the findings of this study that Lesser White-fronted Geese migrated to western Europe in those days. More recent studies estimated the number of Lesser White-fronted Geese currently migrating through and/or wintering in Germany to be at least 50 birds annually (Mooij 1995, Mooij \& Heinicke 2008), which indicates that this flyway is not irrelevant.

Largely based on observations from Finland and northern Sweden from the period between 1900 and 1980 and Finnish literature data (Hortling 1929a, b, Merikallio 1915, 1920, Munsterhjelm 1911, 1913, Sandman 1892), Norderhaug \& Norderhaug $(1982,1984)$ suggested a migratory route over Finland, which has been quoted in more recent literature (Lorentsen et al. 1999). It was based on poor information and suffered from a large gap of records from staging sites along the Central European flyway. Besides, they did not take into consideration the possibility of a small proportion of Lesser White-fronted Geese migrating along a westerly route as indicated in older literature, e.g. Alphéraky (1904), Niethammer (1938), Rosenius (1937), Schlegel (1877), Witherby et al. (1939).

\section{Migratory network in Europe}

The wintering sites of the western Palaearctic Lesser White-fronted Geese are situated at the positive side of the $0^{\circ} \mathrm{C}$ isotherm for January (Figure 8). According to Nankinov (1992 \& 1994) there are six main migratory routes in Europe and Western Siberia. Two of them lead the geese to western Europe, one from northern Siberia along the arctic coast and the southern coast of the Baltic Sea and the other from northern Fennoscandia along the east coast of Sweden. Five of these routes were also found in this study, whereas the sixth route of Nankinov, which followed the Volga, Kama and Pechora valleys in north-south direction, was not found. But the records instead indicated a new migratory route over the Pripyat and Oka Valleys in a west-east direction (Figure 8B). The existence of a West European migratory route is also indicated by the record of a Lesser White-fronted Goose ringed in Swedish Lapland in June 1956 and shot in southwestern France in November 1959 (Dubois et al. 2000, Fransson \& Petterson 2001).

In the past decade a number of Lesser Whitefronted Geese were marked with satellite transmitters in northernmost Fennoscandia, the Polar Ural and the Puturana Mountains (Aarvak \& Øien 2003, Lorentsen et al. 1998, Morozov \& Aarvak 2004, www.piskulka.net). The records of these birds showed migratory routes through western Siberia as well as along the Russian and Baltic coast and through East Europe to Greece and Iraq. These data were combined with the records of this study (Figure 8A).

In most West European countries Lesser Whitefronted geese were found associated with Taiga Bean Geese Anser fabalis fabalis and Russian Greater White-fronted Geese (Davies 1949, Davis \& Scott 1946, Kampe-Persson 2007, Mooij \& Heinicke 2007, 2008, Mooij et al. 2008, Watson 1955, Smith 1974), which indicate that these birds originated from Fennoscandia as well as from Russia. 
Data from the western migratory route gathered by Kampe-Persson (2008), combined with the results of this study, indicate that Lesser White-fronted Geese of Jämtland and southern Lapland seem to have migrated over Sweden to western Europe, whereas the breeding birds of northern Lapland and Finmark most likely mainly migrated over Finland and Hungary to eastern Europe (Kampe-Persson 2008, Mooij et al. 2008). Most of the breeding birds of the western part of arctic Russia seem to migrate to Europe along the coast of the White and Baltic Seas (Aarvak \& Øien 2003, Lorentzen et al. 1998), whereas most of the eastern Russian and western Siberian breeding birds mainly migrate along the western Siberian plain to northern Kazakhstan and subsequently to the wintering sites in the Black Sea-Caspian Sea region (Morozov \& Aarvak 2004).

As a result of this migratory network in most staging and wintering areas there is a mixture of birds from different breeding areas and new pair bonds can be formed between birds from different breeding sites, and males follow their female to her native breeding site. This mechanism, ensuring genetic exchange between different breeding populations and preventing the development of genetic subunits, was genetically confirmed by Ruokonen et al. 2004.

The drastic decline of the Fennoscandian breeding population, starting in the southern part of the breeding area and subsequently spreading to the north resulted in a decline of the number of Lesser White-fronted Geese using the West European/Atlantic migratory route. As a result Lesser Whitefronted Geese observed in western Europe in the past decades most likely mainly belonged to the Russian breeding population.

Besides birds of wild origin, birds of the Swedish Lesser White-fronted Goose reinforcement project winter in western Europe, especially in the Netherlands since the beginning of the 1980s. These birds reach their wintering sites by a rather narrow migratory corridor from Sweden crossing the German Wadden Sea coast to the Netherlands (Mooij \& Heinicke 2007, 2008). During the past decade the birds of this increasing population started spreading and most likely started to mix up with the birds of wild origin, i.e. both populations will be increasingly integrated in the coming years.

\section{Historical population level and development}

The first estimate of the population size of the Lesser White-fronted Goose was made by Uspen- ski (1965), who estimated the world population to be at least 100,000 birds in the 1950s. This estimate must have been considerably too low because this study indicates a population level only in the Western Palearctic to have decreased from c. 200,000 in the early 20 th century to c. 100,000 in the 1970 s and currently less than 10,000 birds. But maybe this decline was even bigger. According to Bauer \& Glutz von Blotzheim (1968), Buisman \& Van Oort (1939), Deutsche Jäger-Zeitung 1916, Flint \& Krivenko (1990), Grimpe (1933), Krivenko (1996), Lebret (1952), Niethammer (1938), Ringleben (1957), Schlegel (1877) and Van Oort (1937) waterbird numbers in Europe have declined considerably since the middle of the 19th century, so the decrease of Lesser White-fronted Goose numbers could have started already in the 19th century. In consideration of the estimates of Flint \& Krivenko (1990) and Krivenko (1996), who stated that the present waterbird populations on the territory of the former USSR only reach about one third of the level of the 1850s and that the populations of the forest-tundra/tundra even decreased faster and reached one third of the 1850-level already in the 1960s/1970s, it does not seem unrealistic that the Lesser White-fronted Goose population may have reached a level of 250,000-350,000 individuals in the middle of the 19 th century.

\section{Hunting}

Based on conservative estimates of the annual goose bags of several goose species in the Western Palearctic it seems that in spite of the fact that nowadays the species is a non-quarry species in its complete living range, more than 2400 Lesser White-fronted Geese (i.e. $20-25 \%$ of the population) are shot each year (Mooij 2005). Yerokhow et al. 2008 estimated the annual Lesser White-fronted Goose bag for northern Kazakhstan to be about 2500 individuals, which means that the total bag in western Palearctic must be considerably higher than 2400. With a population size of 8000-13,000 individuals, annual loss due to hunting is at least $20-30 \%$ of the population. On top of this an annual natural mortality of at least $5 \%$ has to be added, which brings annual mortality to at least $25-35 \%$. The most alarming aspect is that these birds are shot by accident during regular goose hunting of other species, especially because they cannot easily be distinguished from the look-alike Greater Whitefronted Goose (Yerokhow et al. 2008, Yerokhow, pers.com.).

Small Lesser White-fronted Goose flocks tend 
to associate with other goose species. As a result of the declining population this social behaviour will be strengthened in the future. The only effective protection measure would therefore be to ban all goose hunting or at least Greater White-fronted Goose hunting from all Lesser White-fronted Goose sites (Kruckenberg \& Mooij 2007, Tolvanen et al. 2009).

\section{Conclusions and consequences for the protection of the species}

Based on the results of this study it can be concluded that

1. in the 19th century the Lesser White-fronted Goose bred in the Eurasian shrub tundra from Fennoscandia to Chukotka and migrated in winter to areas south of the zero degree isotherm from Spain and Great Britain in the west to China and Japan in the East.

2. the world population of the Lesser White-fronted Goose was probably considerably higher than 100,000 birds in the 1950s.

3 . the decline of the Lesser White-fronted Goose population probably started already at the middle of the 19th century.

4. there is a considerable number of data, which indicate that Lesser White-fronted Geese not only migrated over western Siberia and eastern Europe, but also over western Europe, but it is not possible to decide, which migratory route has been the most important one.

5 . in spite of all protection measures hunting is still one of the major threats of the long-term survival of the Lesser White-fronted Goose, which only can be brought to an end if (Greater White-fronted) goose hunting is banned from all staging areas of the species.

\section{Acknowledgments}

I thank a number of colleagues for their valuable information and some anonymous referees for their useful remarks and helpful suggestions at a previous version of the article.

\section{References}

Aarvak, T. \& Øien, I.J. 2003. Moult and autumn migration of non-breeding Fennoscandian Lesser White-fronted Geese Anser erythropus mapped by satellite telemetry. Bird Cons. Int. 13: 213-226.

Aarvak, T. \& Timonen, S. 2004. Fennoscandian Lesser White-fronted Goose conservation project. Annual Report 2001-2003. WWF Finland Report 20, Helsinki/NOF Rap- portserie Report no. 1-2004, Helsinki-Klæbu.

AEWA (Agreement on the Conservation of African-Eurasian Migratory Waterbirds) 2008. International Single Species Action Plan for the Conservation of the Lesser Whitefronted Goose (Western Palearctic population) Anser erythropus. AEWA Technical Series No. 36

Alphéraky, S. 1904. Geese of Russia. Kutschnerew \& Co, Moscow.

Bauer, K.M. \& Glutz von Blotzheim, U.N. (eds.) 1968. Handbuch der Vögel Mitteleuropas. Band 2: Anseriformes. 2. Akad. Verlagsges., Frankfurt/Main.

Buisman, H.H. \& van Oort, G.J. 1939. Verslag van de Eenden-, Zwanen- en Ganzenenquête. Ardea 28: 38-47.

Davies, H. 1949. Lesser White-fronted Goose in Norfolk. British Birds 42: 95.

Davis, H.H. \& Scott, P. 1946. Lesser White-fronted Goose on the Severn. British Birds 39: 77-79.

Dementiev, G.P. \& Gladkov, N.A. 1952. Birds of the Soviet Union. Vol. 4. 1967 translation, Israel Program for Scientific Translation, Jerusalem.

De Smet, G. 2005. Status and origin of rare geese in Belgium. Oriolus 71 (Supplement): 76-89.

Deutsche Jäger-Zeitung (ed.) 1916. Riesenthals Jagdlexikon. Neumann, Neudamm.

Drobovtsev, V. 1972. Charakter of the spring and autumn passage of geese in the North-Kazakhstan region. Pp. 132-138 in Geese in the USSR (Kumari, E., ed). Proceedings of a conference, Estonia, Mai 1970, Tartu.

Dubois, P.J., Le Maréchal, P., Olioso, G. \& Yésou, P. 2000. Inventaire des oiseaux de France. Avifaune de France métropolitaine. Nathan, Paris.

Dzieciolowski, R. \& Frankiewicz, E. 1970. Dzikie Gesi. Warszawa

Eykman, C., Hens, P.A., van Heurn, F.C., ten Kate, C.G.B., van Marle, J.G., van der Meer, G., Tekke, M.J. \& de Vries, T.G. 1941. De Nederlandse vogels. Wageningen.

Faragó, S. 1995. Geese in Hungary 1986-1991. Numbers, Migration and Hunting Bags. IWRB Publication 36.

Flint, V.Ye. \& Krivenko, V.G. 1990. The present status and trends of waterfowl in the USSR. Pp. 23-26 in Managing Waterfowl Populations (Matthews, G.V.T., ed.). IWRB Spec. Publ. 12.

Fransson, T. \& Petterson, J. 2001. Svensk ringmärkningsatlas. Vol 1. Swedish Museum of Natural History/Swedish Ornithological Society, Stockholm.

Frieling, H. 1936. Exkursionsbuch zum Bestimmen der Vögel in freier Natur nach ihrem Lebensraum geordnet. Springer, Berlin.

Grimpe, G. 1933. Der Volks-Brehm. Bibliographisches Institut, Leipzig.

Handrinos, G.I. \& Goutner, V. 1990 On the occurrence of the Lesser White-fronted Goose Anser erythropus in Greece. J. Orn. 131: 160-165

Heinicke, T. \& Mooij, J.H. 2005. Neue Erkenntnisse zum Auftreten und Schutz der Zwerggans in Deutschland. DDA-Wasservogelrundbrief August 2005: 10-12.

Hortling, I. 1929a. Ornithologisk handbook med beskrivning över alla $i$ Finland anträffade fågelarter och raser jämte avbildningar och enkom utförda ving- och äggmått m.m. samt namnförklaringar. J. Simelii Arvingars Boktryckeri $\mathrm{AB}$, Helsingfors.

Hortling, I. 1929b. Zum Frühjahrszuge an der Westküste Finnlands. Journal f. Ornithologie Ergänzungsband 2: 
93-105.

Hudson, W.H. 1895. British Birds. Longmans, Green \& Co, London and New York.

Kampe-Persson, H. 2004. Is Doñana of importance for the Lesser White-fronted Goose Anser erythropus? Anuario Ornithológico de Doñana 1: 217-225.

Kampe-Persson, H. 2008. Historical occurrence of the Lesser White-fronted Goose Anser erythropus in the Atlantic flyway. Ornis Svecica 18: 69-81

Klemm, W. \& Kohl, S. 1988. Die Ornis Siebenbürgens. Band III Studia Transsylvanica 8/III Böhlau, Köln.

Koffijberg K., Cottaar, F. \& van der Jeugd, H. 2005. Pleisterplaatsen van Dwergganzen Anser erythropus in Nederland. SOVON-informatierapport 2005/06. SOVON Vogelonderzoek Nederland, Beek-Ubbergen.

Krivenko, V.G. 1996. Wildfowl (Anatidae) in the former USSR. Gibier Faune Sauvage, Game Wildlife 13/Wetlands International Publication 40: 303-317.

Kruckenberg, H. \& Mooij, J.H. 2007. Warum Wissenschaft und Vogelschutz die Gänsejagd in Deutschland ablehnen. Ber. Vogelschutz 44: 107-119.

Kumari, E. \& Jögi, A. 1972. Passage of Geese through the Baltic area. Pp. 80-92 in Geese in the USSR (Kumari, E., ed.). Proceedings of a conference, Estonia, Mai 1970. Tartu.

Lebret, T. 1952. Suizende Wieken. Brill, Leiden.

Leibak, E., Lilleleht, V.\& Veromann, H. (Eds) 1994. Birds of Estonia. Estonian Academy Publishers, Tallinn.

LOB (2007). Mazā zoss Anser erythropus. www.putni.nerealitate.lv. Down-loaded 30 June 2007.

Lorentsen, S.-H., Øien, I.J. \& Aarvak, T. 1998. Migration of Fennoscandian Lesser White-fronted Geese Anser erythropus mapped by satellite telemetry. Biological Conservation 84: 47-52.

Lorentsen S.-H., Øien, I.J., Aarvak, T., Markkola, J., Von Essen, L., Faragó, S., Morozov, V., Syroechkovsky Jr, E.E. \& Tolvanen, P.1999. Lesser White-fronted Goose Anser erythropus. Pp. 144-161 in Goose populations of the Western Palearctic. A review of status and distribution (J. Madsen, G. Cracknell \& A.D. Fox, eds.). Wetlands International Publ. 48.

Madsen, J., Cracknell, G. \& Fox, A.D. 1999. Goose populations of the Western Palearctic. A review of status and distribution. Wetlands International Publ. 48.

Merikallio, E.F. 1915. Fjällgåsens flyttningsväg öfver trakterna kring Uleåborg. Finlands Jakttidskrift 12: 311-313.

Merikallio, E. 1920. Flyttar fjällgåsen (Anser erythropus L.) till Lappland öfver trakterna kring Uleåborg? Finlands Jakttidskrift 15: 81-88 \& 110-114.

Middendorf, A. Th. v. 1853. Sibirische Reise. Band II, Theil 2. Wirbeltiere, Erste Lieferung. Kaiserliche Akademie der Wissenschaften, St. Petersburg.

Middendorf, A. v. 1867. Sibirische Reise. Band IV. Uebersicht der Natur Nord- und Ost-Sibiriens. Theil 2. Erste Lieferung. Die Thierwelt Sibiriens. Kaiserliche Akademie der Wissenschaften, St. Petersburg.

Mooij, J.H. 1995. Ergebnisse der Gänsezählungen in Deutschland 1988/89 bis 1992/93. Vogelwelt 116: 119-132.

Mooij, J.H. 2005. Protection and use of waterbirds in the European Union. Beitr. Jagd- \& Wildforschung 30: 49-76.

Mooij, J.H. \& Heinicke, T. 2007. Neue Erkenntnisse zum Auftreten und Schutz der Zwerggans Anser erythropus in Deutschland. Charadrius 43: 171-184.
Mooij, J.H. \& Heinicke, T. 2008. Status, distribution and numbers of the Lesser White-fronted Goose Anser erythropus in Germany. Vogelwelt 129: 281-292.

Mooij, J.H., Hansson, P., Kampe-Persson, H. \& Nilsson, L. 2008. Analysis of historical observations of Fennoscandian Lesser White-fronted Geese Anser erythropus in Sweden and the West Palearctic. Vogelwelt 129: 269-280.

Morozov, V.V. 2006. The Lesser White-fronted Goose Anser erythropus at the verge of the millennium. In Waterbirds around the world (Boere, G.C., Galbraith, C.A. \& Stroud, D.A., eds). The Stationery Office, Edinburgh, UK. 960 pp.

Morozov, V.V. \& Aarvak, T. 2004. Wintering of the Lesser White-fronted Geese breeding in the Polar Urals. Casarca 10: $156-162$.

Morozov, V.V. \& Syroechkovski Jr, E.E. 2005. Lesser White-fronted Goose at the turn of the millennium. $\mathrm{Ca}$ sarca - Supplement 1: 91-138.

Munsterhjelm, L. 1911. Om fågelfaunan i Könkämädalen uti Lappmarken. Acta Societatis pro Fauna et Flora Fennica 34(8), $81 \mathrm{pp}$.

Munsterhjelm, L. 1913. Fjällgåsen (Anser erythropus) i Skandinavien och Finland. Tidskrift för Jägare och Fiskare 1: 1-5.

Nankinov, D. 1992. Lesser White-fronted Goose (Anser erythropus) migration routes, wintering sites and conservation in Western Eurasia. Gibier Faune Sauvage 9: 257-268.

Nankinov, D.N. 1994. Migratsii $i$ zimovki ptits na Balkanskom polyostrove. Dissertatitsija. Sankt-Peterburskiy Gosudarstvenniy Universitet.

Naumann, J.F. 1842. Naturgeschichte der Vögel Deutschland. Bd XI, Leipzig.

Niethammer, G. (ed.) 1938. Handbuch der Deutschen Vogelkunde. Vol. 2. Akademische Verlagsgesellschaft, Leipzig.

Nilsson, S. 1858. Skandinavisk fauna, Foglarna. Gleerups, Lund.

Norderhaug, A. \& Norderhaug, M. 1982. Anser erythropus in Fennoscandia. Aquila 89: 93-101.

Norderhaug, A. \& Norderhaug, M. 1984. Status of the Lesser White-fronted Goose, Anser erythropus, in Fennoscandia. Swedish Wildlife Res. 13:171-185.

Noskov, G.A. (ed.) 2002. Pp. 348-349 in Red Data Book of Nature of the Leningrad Region. Vol. 3. Animals, St.Petersburg.

Ogilvie, M.A. \& Wallace, D.I.M. 1975. Field identification of grey geese. British Birds 68: 57-67.

Panchenko, V. \& Priklonski, S. 1972. The specifik composition of the numbers of geese during the spring migration in the area of the Oka Nature Reserve. Pp. 98-10 in Geese in the USSR (Kumari, E., ed.). Proceedings of a conference, Estonia, Mai 1970. Tartu.

Paynter, D. 1996. Counts of Lesser White-fronted Geese in Azerbaijan, January/February 1996. Wetlands International Goose Specialist Group Bulletin 8:7-8.

Pedall, I., Gonzalez, J., Sauer-Gürth, H. \& Wink, M. 2007. Genetic analysis of captive Lesser White-fronted Geese (Anser erythropus) in Germany. Vogelwelt 128: 304-309.

Persson, H. 2000. Occurence of the Lesser White-fronted Goose in Spain, up to 1999. In Fennoscandian Lesser White-fronted Goose conservation project - Annual report 1999 (Tolvanen, P., Øien, I.J. \& Ruokolainen, K., eds). WWF Finland Report No 13 \& Norwegian Ornithological Society, NOF Rapportserie Report No 1-2001: 
51-52.

Persson, H. 2004. Lesser White-fronted Geese shot in Spain. In Fennoscandian Lesser White-fronted Goose conservation project - Annual report 2001-2003 (Aarvak, T. \& Timonen, S., eds.) WWF Finland Report No 20 \& Norwegian Ornithological Society, NOF Rapportserie Report No 1-2004: 50.

Prokosch, P. \& Hötker, H. (eds.) 1995. Faunistik und Naturschutz auf Taimyr - Expeditionen 1989-1991. Corax 16 (Special Issue).

Raudonukis, L. \& Shvazhas, S. 1991. A short note on goose migration in Lithuania. Ardea 79: 123-124.

Ringleben H. 1957. Die Wildgänse Europas. Ziemsen, Wittenberg Lutherstadt.

Rogacheva, H. 1992. The Birds of Central Siberia. Husum.

Rosenius, P. 1937. Sveriges fåglar och fågelbon. Vol. 4. C. W. K. Gleerups förlag, Lund.

Ruokonen, M, Kvist, L., Aarvak, T., Markkola, J., Morozov, V.V., Øien, I.J., Syroechkovsky Jr., E.E., Tolvanen, P. \& Lumme, J. 2004. Population genetic structure and conservation of the lesser white-fronted goose Anser erythropus. Conservation Genetics 5: 501-512.

Salmen, H. 1980. Die Ornis Siebenbürgens. Band I. Studia Transsylvanica 8/I. Böhlau, Köln.

Sandman, J.A. 1892. Fogelfaunan på Karlö. Meddelanden af Societatis pro Fauna et Flora Fennica 17.

Schlegel, H. 1877. De Vogels van Nederland. Funke, Amsterdam.

Scott. P. 1939. Wild Chorus. Country Life, London.

Sterbetz, I. 1968. Der Zug der Zwerggans auf der Ungarischen Puszta. Ardea 56: 259-266.

Sterbetz, I. 1976. Development of wild-geese migration on the Hungarian gathering-places. Aquila 82: 181-194.

Sterbetz, I. 1982. Migration of Anser erythropus and Branta ruficollis in Hungary 1971-1980. Aquila 89: 107-114.

Smith, F.R. 1974. Report on rare birds in Great Britain in 1973 (with additions for ten previous years). British Birds 67: $310-348$.

Stresemann, E. (ed.) 1961. Exkursionsfauna von Deutschland. Wirbeltiere. Volk und Wissen Volkseigener Verlag, Berlin.

Švažas, S. 1996. The Lesser White-fronted Goose in Lithuania. Wetlands International Goose Specialist Group Bulletin 7: 8-9.

Švažas, S., Stanevicius, V. \& Čepulis, M. 1997. The status, numbers and distribution of swans and geese in Lithuania. Acta Zoologica Lituanica, Ornithologia 6: 66-78.

Švažas, S., Stanevicius, V. \& Čepulis, M. 1998. Inventory of important staging areas for waterfowl in Lithuania. Acta Zoologica Lituanica, Ornithologia 8: 163-168.

Tischler, F. 1914. Die Vögel der Provinz Ostpreussen. Junk, Berlin.

Thienemann, J. 1907. VI. Jahresbericht (1906) der Vogelwarte Rositten der Deutschen Ornithologischen Gesellschaft. J. Orn. 55: 481-548.

Thienemann, J. 1908. VII. Jahresbericht (1907) der Vogelwarte Rositten der Deutschen Ornithologischen Gesellschaft. J. Orn. 56: 393-445.

Tkachenko, Ye.E. \& Litvinova, N.A. 1990. Wintering of Waterfowl in Azerbaidzhan. Pp. 32-33 in Managing Waterfowl Populations (Matthews, G.V.T., ed.). Proceedings of an IWRB-Symposium, Astrakhan, USSR, 2-5 October 1989. IWRB Special Publication No. 12.
Tolvanen, P. \& Pynnönen, J. 1998. Monitoring the autumn migration of Lesser White-fronted Goose Anser erythropus and other geese in NW Kazakhstan in October 1996. Pp. 19-20 in Finnish Lesser White-fronted Goose Conservation Project (Tolvanen, P., Ruokolainen, K., Markkola, J. \& Karvonen, eds.). WWF Finland Report 9.

Tolvanen, P., Toming, M. \& Pynnönen, J. 2004. Monitoring of Lesser White-fronted Geese in western Estonia in 2001-2003. In Fennoscandian Lesser White-fronted Goose conservation project. Report 2001-2003 (Aarvak, T. \& Timonen, S., eds.). WWF Finland Report No 20 \& Norwegian Ornithological Society, NOF Rapportserie report No. 1-2004: 9-13.

Tolvanen, P., Tsougrakis, Y. \& Øien, I.J. 2009. Overview of results and conclusions from the international Lesser White-fronted Goose LIFE project. In Conservation of Lesser White-fronted Goose on the European migration route. Final report of the EU LIFE-Nature project 20052009 (Tolvanen, P., Øien, I.J. \& Ruokolainen, K., eds.). WWF Finland Report No 27, NOF Rapportserie Report No 1-2009: 5-11.

Tomiałojc, L. 1990. Ptaki Polski. Rozmieszczenie i liczebnosc. Pánstwowe Wydawnictwo Naukowe, Warszawa.

Uspenski, S.M. 1965. Die Wildgänse nordeurasiens. Neue Brehm Bücherei, Wittenberg-Lutherstadt.

Van Impe, J. 1982. The Lesser White-fronted Goose in the south of the province of Zeeland (Netherlands). Veldornithologisch Tijdschrift 5: 130-140.

Van Oort, G.J. 1937. Enquête naar de stand der Zwanen, Ganzen en Eenden. Ardea 26: 109.

Van Oort, K.D. 1909. Contribution to our knowledge of the Avifauna of the Netherlands, being a list of all the species of birds hitherto observed, with special references to specimens in the Leyden Museum. Notes of the Leyden Museum 30: 129-224.

Vinogradov, V.G. 1990. Anser erythropus in the USSR. Pp. 199-203 in Managing Waterfowl Populations (Matthews, G.V.T., ed.). Proceedings of an IWRB-Symposium, Astrakhan, USSR, 2-5 October 1989. IWRB Special Publication No. 12.

Vlaamse Avifaunacommissie 1989. Vogels in Vlaanderen. Voorkomen en Verspreiding. C.I.P. Koninklijke Bibliotheek Albert I, Bornhem.

Von Essen, L. 1982. An effort to reintroduce the Lesser White-fronted Goose Anser erythropus into the Scandinavian Mountains. Aquila 89:103-105.

Von Essen, L. 1991. A note on the Lesser White-fronted Goose Anser erythropus in Sweden and the result of a reintroduction scheme. Ardea 79(2): 305-306.

Von Essen, L. 1996. Reintroduction of lesser white-fronted geese (Anser erythropus) in Swedish Lapland (19811991). Gibier Faune Sauvage, Game Wildl. 13: 11691180.

Von Transehe, N. 1965. Die Vogelwelt Lettlands. Mit Berücksichtigung der Nachbargebiete. Verlag Harro von Hirschheydt, Hannover-Döhren.

Watson, D. 1955. Lesser White-fronted Goose in Kirkcudbright. British Birds 48: 323-325.

Witherby, H.F., Jourdain, F.C.R., Ticehurst, N.F. \& Tucker, B.W. 1939. The Handbook of British Birds. Vol. III. Witherby, London.

Yeatman-Berthelot, D. 1991. Atlas des Oiseaux de France en hiver. SEOF, Paris. 
Yerokhov, S., Berezovikov, N., Kellomäki, E., Ripatti, N. \& Kahanpää, L. 2008. Results of ten years monitoring of the autumn migration of geese in the Kostanay Region, N.W. Kazakhstan. Vogelwelt 129: 204-214.

Žalakevičius, M. 1998. Results of the long-term waterfowl migration research in Lithuania. Proceedings of OMPO International meeting Reproduction and important habitats of migratory birds of the Western Palearctic. Acta Zoologica Litunaica Ornithologica 8 (Special issue): 15-18.

\section{Sammanfattning}

Denna uppsats är en översikt av den historiska dokumentationen av fjällgåsens förekomst i Europa. Den baserar sig främst på litteraturuppgifter men delvis även på personlig information. Målet är särskilt att kartlägga artens flyttstråk. Eftersom utsläpp av i fångenskap uppfödda fjällgäss började i Sverige 1981, och dessa inte kan skiljas från individer från det ursprungliga vilda beståndet, har jag begränsat analysen till att omfatta rapporter fram till 1982.

Efter att ha sorterat bort dubbelrapportering av samma individer har jag accepterat 986 rapporter för analysen. Antalet individer per rapport ökade fram till 1920-talet men har därefter vatit i huvudsak stabilt (Tabell 1). Ett undantag är 1970-talet, då antalet var högre på grund av ett specialprojekt i Ungern. De flesta rapporter avser få individer och rapporter om fler än hundra finns bara från det svenska häckningsområdet (1910-1940-talen) och från Evros delta i Grekland (1960-1970-talen).

Antalet rapporter ökade under 1930-talet, minskade under kriget för att därefter åter öka trots den drastiska beståndsnedgången, något som illustrerar det ökande intresset för fjällgåsen (Figur 1). I samma figur visas fördelningen av observationerna från häcknings- och ruggningsområden, rastområden och övervintringsområden. Under alla perioderna dominerar rapporter från rastområden längs flyttstråken.

Rapporternas geografiska fördelning visas i Figurerna 2-3. Från före 1900 var fynden få, främst exemplar i museisamlingar, totalt 28 , spridda på många länder men med flest (12 st.) i Tyskland.

Säsongsfördelningen av fynden framgår av kartorna i Figur 4-7. Sommarfynden utanför häck- nings- och ruggningsområdet avser troligen fåglar som stannat på grund av skadeskjutning eller yngre fåglar som ännu inte börjat häcka (Bottenkusten). Höstfynden är spridda längs flyttvägarna över en stor del av Europa och västra Sibirien. Vinterfynden ligger klart längre söderut och övervintringsområdet når ända till Medelhavsländerna. Övervintringen sker huvudsakligen på plussidan av vinterns nollgradersisoterm (Figur 8b). Vårfynden visar åter en koncentration norrut.

Den tidiga historiska utvecklingen av fjällgåsbeståndet är svår att klarlägga eftersom rapporterna är få från 1700- och 1800-talen. Dessutom var fjällgåsens status som art förr oklar och man skilde ofta inte på fjällgås och bläsgås. De uppgifter som finns kann dock tolkas så att det inte är orealistiskt att tro att det fanns omkring 200.000 fjällgäss i västra Paläarktis under första halvan av 1900-talet. Detta bestånd hade sannolikt halverats fram till 1970-talet. Därefter har nedgången fortsatt till 15.000 fåglar 1990 och 10.000 år 2000.

Jakten är omfattande. Tabell 2 visar andelen fjällgäss i den totala gåsjakten för olika länder. Trots att fjällgåsen länge varit fridlyst på de flesta håll skjuts i dag årligen ungefär 2400 individer. Detta beror på att man sällan hinner skilja fjällgäss från andra gäss, särskilt bläsgås, i jaktsituationen.

Vad gäller flyttvägarna visar den historiska fyndbilden (alla fynd samlade i Figur 8a) på ett antal olika flyttvägar (Figur 8b). Bland annat torde det stå helt klart att icke obetydliga antal flyttade till Västeuropa. Vad gäller Skandinavien verkar det som om fjällgäss från Jämtland och södra Lappland flyttade till Västeuropa medan de från norra Lappland och Finnmark flyttade via Finland till Sydosteuropa. De flesta av flyttsråken har varit desamma under historiens gång. Bara något enstaka har försvunnit eller tillkommit.

Uppskattningen att det årligen skjuts 2400 fjällgäss innebär att jakten tar $20-25 \%$ av beståndet. Detta är dock ett minimum eftersom en omfattande jakt i Kasakstan inte ingår i värdet. Det mest alarmerande är att fridlysning inte fungerar eftersom det i praktiken inte går att skilja ut fjällgässen under jakten. Det enda som skulle fungera är totalförbud för gåsjakt, eller åtminstone totalförbud för bläsgåsjakt, i alla områden där fjällgäss vistas. 